75 years of Agricultural University - Plovdiv

JUBILEE SCIENTIFIC INTERNATIONAL

CONFERENCE Plovdiv 26-28 November 2020
PERSPECTIVES ON AGRICULTURAL SCIENCE AND INNOVATIONS FOR SUSTAINABLE FOOD SYSTEMS

\title{
DOI: 10.22620/agrisci.2021.30.007 \\ SELECTION OF PERSPECTIVE EARLY MUTANT LINES OF BEAN (PHASEOLUS VULGARIS L.) IN DROUGHT CONDITIONS
}

\author{
Tsvetanka Dintcheva*, Hriska Boteva, Nasya Tomlekova, Slavka Kalapchieva
}

Maritsa Vegetable Crops Research Institute, Plovdiv

*E-mail: tdintcheva@gmail.com

\begin{abstract}
In 2020 a field experiment was conducted with mutant lines of common bean from $\mathrm{M}_{4}$ generations at the Maritsa Vegetable Crops Research Institute, Plovdiv. The aim of the study was to determine the productivity of plants in drought conditions. Twenty four mutant lines were studied in two variants: optimal (non-treated) and reduced (treated) irrigation regimes. A description of the mutant lines was made according to the following features: color: coloring of the flag; beans - length without beak; bean shape in cross section (through the seed); beans-basic coloring; flowering time.

Phenological data were collected for phenophases: budding, flowering, fruit size, consumption and botanical maturity. At consumption maturity, biometric measurements were made of 5 plants per repetition on the following indicators: fresh weight $(\mathrm{g})$ of a plant; number and fresh mass $(\mathrm{g})$ of green beans per plant; length $(\mathrm{cm})$ and width $(\mathrm{cm})$ of beans, total fresh biomass $(\mathrm{g})$.

The highest productivity found among the treated plants in consumption maturity were the early mutant lines M 564-193-9-1-1 and 564-193-9-1-2, followed by M 564-190-1-1-1, M 564-110-1-2, and M 564-191-1-1-2, compared to the parent line L 564 and all the rest of early mutant lines. The treated plants developed the phenophases 7-10 days later than those with optimal watering.

Keywords: Phaseolus vulgaris L., mutants, morphology, productivity, drought stress.

\section{INTRODUCTION}

Drought stress is the most serious agronomic challenge in growing beans in some areas of the world (Rao, 2014; Rippke et al., 2016). Over the last decade, the duration of rainless periods has increased significantly, resulting in large losses in yields (Dai, 2013). Therefore, there is a need for developing new varieties tolerant to long periods of drought, guaranteeing relatively high yields.

Legumes are widespread and consumed worldwide, providing more than $69 \%$ of the protein and $30 \%$ of the fat needed for human

agriculture due to the minimum requirements for fertilization and due to the symbiotic relationship with the soil microorganisms, while increasing soil fertility and reducing the amount of mineral fertilizers in crop rotations (Piha and Munns, 1987; Figueiredo et al., 2008 Olivera et al., 2004).

The aim of the study was to evaluate and select mutant genotypes of beans in drought conditions. Selected mutant genotypes will be used for a subsequent selection and developing varieties tolerant to water deficit which will guarantee a good productivity in the changing climatic conditions.
\end{abstract} diet. Beans (Phaseolus vulgaris L.) are one of the main sources of protein, ranging in content from $60 \%$ to $90 \%$, depending on the genotype (Koehler, 1987).

Legumes are also used in sustainable

\section{MATERIALS AND METHODS}

The study was conducted in 2020 (a study conducted in continuation from 2019) at 
75 years of Agricultural University - Plovdiv JUBILEE SCIENTIFIC INTERNATIONAL CONFERENCE Plovdiv 26-28 November 2020
PERSPECTIVES ON AGRICULTURAL SCIENCE AND INNOVATIONS FOR SUSTAINABLE FOOD SYSTEMS the Maritsa Vegetable Crops Research Institute, Plovdiv with a bean population of 24 early mutant lines in $\mathrm{M}_{4}$ generation. They were grown in the following conditions: Control - untreated plants grown in optimal irrigation regime (10 plants in one replication) and Treated plants with reduced irrigation regime / drought (water deficit) (10 plants in three replications). Watering is done through a drip system. Until the beginning of the budding phase, the plants of both variants are watered with an optimal irrigation rate $\left(30-40 \mathrm{~L} / \mathrm{m}^{2}\right)$. The treatment of the plants (50\% of all plants) started in the beginning of budding. Plants from the early mutant lines were grown under conditions without watering for 15 days until reaching 30 $\%$ of soil humidity (from $16 / 07$ to $31 / 07$ ). Until the end of the vegetation, an irrigation regime was maintained with 7 days of drying of the treated plants (watering once a week), and the control plants were watered twice a week to maintain optimal soil humidity. A total of 40 plants were selected from the previously selected mutant lines and the parent.

The plants were grown by the technology for the late field production, according to the scheme: $100+60 / 5-6 \mathrm{~cm}$ and the sowing date, June 15. The amount of fertilizers was determined after the agrochemical analysis of the soil. With the presowing treatment, fertilization was performed with $200 \mathrm{~kg} /$ ha triple superphosphate and 160 $\mathrm{kg} /$ ha potassium sulfate in the recommended norms, according to a preliminary agrochemical analysis. Ammonium nitrate was applied twice during the growing season at $100 \mathrm{~kg} / \mathrm{ha}$ : with first hoeing and after 20 days.

Phenotypic observations were made and the dates of the phenophases were taken into account: budding, flowering, knotting, consumption and botanical maturity. The beginning of the phenophase is considered in 25 $\%$ of the plants in the crop, and for all plants in $75 \%$.
A description of the mutant lines was made according to the following features: color: coloring of the flag - white, pinkish white, pink, violet; beans - length without beak - many short, short, medium, long, very long; pod-shape in cross section (through the seed) - narrowly elliptical, elliptical to ovoid, heart-shaped, rounded, octagonal shape; beans-basic coloring - yellow, green, purple; flowering time when at least $50 \%$ of the plants have at least one open flower.

At consumption maturity, biometric measurements were made of 5 plants from repetition according to the following indicators: fresh mass $(\mathrm{g})$ of one plant; number and fresh mass $(\mathrm{g})$ of green pods per plant; length $(\mathrm{cm})$ and width $(\mathrm{cm})$ of pods, total fresh biomass $(\mathrm{g})$.

\section{RESULTS AND DISCUSSION}

Phenotypic reports showed differences in plant development within mutant lines under the different experimental conditions. It was found that the treated plants are delayed in their development and the phenophases budding and flowering occur 7-10 days later compared to those with optimal watering regime (Table 1). The treated plants start the phenophases of knot and consumption maturity about 3 days later, compared to those with optimal watering regime, but botanical maturity occurs about two weeks earlier in some of the mutant lines. This can be explained by the unfavorable growing conditions created due to the 7-day drought period and the combination with dry and rainless weather during the period July-August.

As a natural response of plants in dry weather they shorten their life cycle and reproduce before the drought (Araus et al., 2002). The duration of the vegetation is determined interactively by the genotype and the environment as the main factors that influence the ability of the crop to avoid climatic stresses (Dingkuhn and Asch, 1999). 
75 years of Agricultural University - Plovdiv JUBILEE SCIENTIFIC INTERNATIONAL CONFERENCE Plovdiv 26-28 November 2020
PERSPECTIVES ON AGRICULTURAL SCIENCE AND INNOVATIONS FOR SUSTAINABLE FOOD SYSTEMS
Table 1. Phenological observations of early mutant lines of common beans, average of the two cultivation variants, after treatment of plants

\begin{tabular}{|l|c|c|}
\hline Phenophases & $\begin{array}{c}\text { Optimal watering } \\
\text { regime } *\end{array}$ & $\begin{array}{c}\text { Drought conditions } \\
\text { (treated plants) } *\end{array}$ \\
\hline \multicolumn{3}{|c|}{ Buttoning } \\
\hline Begining & $6 / 07$ & $13 / 07$ \\
\hline All plants & $13 / 07$ & $17 / 07$ \\
\hline \multicolumn{3}{|c|}{ Flowering } \\
\hline Begining & $13 / 07$ & $17 / 07$ \\
\hline All plants & $17 / 07$ & $20 / 07$ \\
\hline \multicolumn{3}{|c|}{ Tie the fruit } \\
\hline Begining & $20 / 07$ & $24 / 07$ \\
\hline All plants & $24 / 07$ & $27 / 07$ \\
\hline \multicolumn{3}{|c|}{ Consumption maturity } \\
\hline Begining & $24 / 07$ & $27 / 07$ \\
\hline All plants & $27 / 07$ & $30 / 07$ \\
\hline \multicolumn{3}{|c|}{ Botanical maturity } \\
\hline Begining & $19 / 08$ & $3 / 08$ \\
\hline All plants & $24 / 08$ & $19 / 08$ \\
\hline
\end{tabular}

Date of phenological reports
In treated mutant lines, premature leaf drop was observed from the base to the top of the plants in response to the stress factor. A similar reaction was observed in other cultures (DaMatta, 2004).

Description of the mutant lines of beans is presented in Table 2. Segregation is observed on the basis of the color of the flagella. In terms of color and shape of the beans, those without patterns, with a flat-cylindrical shape predominate.

Table 2. Description of plants by phenotypic traits.

\begin{tabular}{|c|c|c|c|c|}
\hline № & Line & Seed color & Pod & $\begin{array}{l}\text { Features of treated } \\
\text { plants }\end{array}$ \\
\hline 1 & L 564 - parent & white & green in color, cylindrical in shape & \\
\hline 2 & Variety Mastilen $11 \mathrm{~b}$ & white & green in color, cylindrical in shape & \\
\hline 3 & $\begin{array}{c}\text { Variety Lodi - } \\
\text { standard for drought } \\
\text { tolerance }\end{array}$ & white & green in color, flat in shape & \\
\hline 4 & M 564-110-1-2 & white & green in color, cylindrical in shape & \\
\hline 5 & M 564-110-1A & white & green in color, cylindrical in shape & \\
\hline 6 & M 564-175-3-1 & pink & green in color, cylindrical in shape & \\
\hline 7 & M 564-175-3-1A & pink & green in color, patterned, flat in shape & \\
\hline 8 & M 564-190-1-1-1 & pink & green in color, patterned, flat in shape & \\
\hline 9 & $\begin{array}{l}\text { M 564-190-3-3-4 } \\
190-1-3\end{array}$ & pink & green in color, patterned, flat in shape & \\
\hline 10 & M 564-190-3-5 & pink & green in color, cylindrical in shape & \\
\hline 11 & M 564-190-3-7-1 & pink & green in color, cylindrical in shape & \\
\hline 12 & M 564-190-3-7-2 & pink & $\begin{array}{l}\text { green in color, with many patterns cylindrical } \\
\text { in shape }\end{array}$ & \\
\hline 13 & M 564-190-3-7-3 & violets & green in color, flat-cylindrical in shape & \\
\hline 14 & M 564-190-3-7-4 & violets & green in color, patterned, cylindrical in shape & \\
\hline 15 & M 564-191-1-1-1 & $\begin{array}{l}\text { mixed - white, } \\
\text { pink and purple }\end{array}$ & $\begin{array}{c}50 \% \text { of the plants are with green pods, } 50 \% \\
\text { with patterns, flat }\end{array}$ & $\begin{array}{c}\text { stronger plant habit than } \\
\text { other mutant lines }\end{array}$ \\
\hline 16 & M 564-191-1-1-2 & creamy & green in color, flat-cylindrical in shape & $\begin{array}{l}\text { stronger plant habit than } \\
\text { other mutant lines }\end{array}$ \\
\hline 17 & M 564-191-1-1-3 & dark pink & green in color, patterned, flat in shape & $\begin{array}{l}\text { stronger plant habit than } \\
\text { other mutant lines }\end{array}$ \\
\hline
\end{tabular}


75 years of Agricultural University - Plovdiv JUBILEE SCIENTIFIC INTERNATIONAL CONFERENCE Plovdiv 26-28 November 2020
PERSPECTIVES ON AGRICULTURAL SCIENCE AND INNOVATIONS FOR SUSTAINABLE FOOD SYSTEMS

\begin{tabular}{|c|c|c|c|c|}
\hline 18 & M 564-191-1-1-4 & light pink & green in color, flat in shape & $\begin{array}{c}\text { stronger plant habit than } \\
\text { other mutant lines }\end{array}$ \\
\hline 19 & M 564-191-1-1-5 & dark pink & green in color, patterned, flat in shape & $\begin{array}{c}\text { stronger plant habit than } \\
\text { other mutant lines }\end{array}$ \\
\hline 20 & M 564-191-1-1-6 & $\begin{array}{l}\text { mixed - pink } \\
\text { and white }\end{array}$ & green in color, patterned, flat in shape & $\begin{array}{c}\text { taller and with a stronger } \\
\text { plant habit than other } \\
\text { mutant lines }\end{array}$ \\
\hline 21 & M 564-193-8-1A & $\begin{array}{l}\text { mixed - light } \\
\text { pink and white }\end{array}$ & green in color, flat in shape & $\begin{array}{l}\text { lower plants and weak } \\
\text { habitat compared to } \\
\text { other mutant lines }\end{array}$ \\
\hline 22 & M 564-193-8-2 & white & green in color, flat-cylindrical in shape & $\begin{array}{l}\text { lower plants and weak } \\
\text { habitat compared to } \\
\text { other mutant lines }\end{array}$ \\
\hline 23 & M 564-193-8-3 & pink & green in color, flat in shape & $\begin{array}{l}\text { lower plants and weak } \\
\text { habitat compared to } \\
\text { other mutant lines }\end{array}$ \\
\hline 24 & M 564-193-8-4 & $\begin{array}{l}\text { white and } \\
\text { violets }\end{array}$ & green in color, flat in shape & $\begin{array}{c}\text { lower plants and weak } \\
\text { habitat compared to } \\
\text { other mutant lines }\end{array}$ \\
\hline 25 & M 564-193-8-5 & $\begin{array}{l}\text { mixed- white } \\
\text { and pink }\end{array}$ & green in color, flat in shape & $\begin{array}{l}\text { lower plants and weak } \\
\text { habitat compared to } \\
\text { other mutant lines }\end{array}$ \\
\hline 26 & M 564-193-9-1-1 & pink & green in color, flat in shape & \\
\hline 27 & M 564-193-9-1-2 & pale pink & green in color, flat in shape & \\
\hline
\end{tabular}

The drought tolerance of the mutant lines was assessed by comparing the biometric indicators - the number and the fresh mass of pods per plant (Fig. 1 and Fig. 2). Measurements have shown that the most plants from the studied mutant lines under water-deficit formed a larger number of pods per plant - from 14 to 37 with a fresh weight of 36.0 to $183.8 \mathrm{~g}$, while the plants under the optimal irrigation regime formed from 8 to 28 pods with a fresh weight of 25.7 to $138.7 \mathrm{~g}$.

The highest productivity in consumption maturity possessed the treated mutant lines № 26 (M 564-193-9-1-1) and № 27 (M 564-193-9$1-2)$.

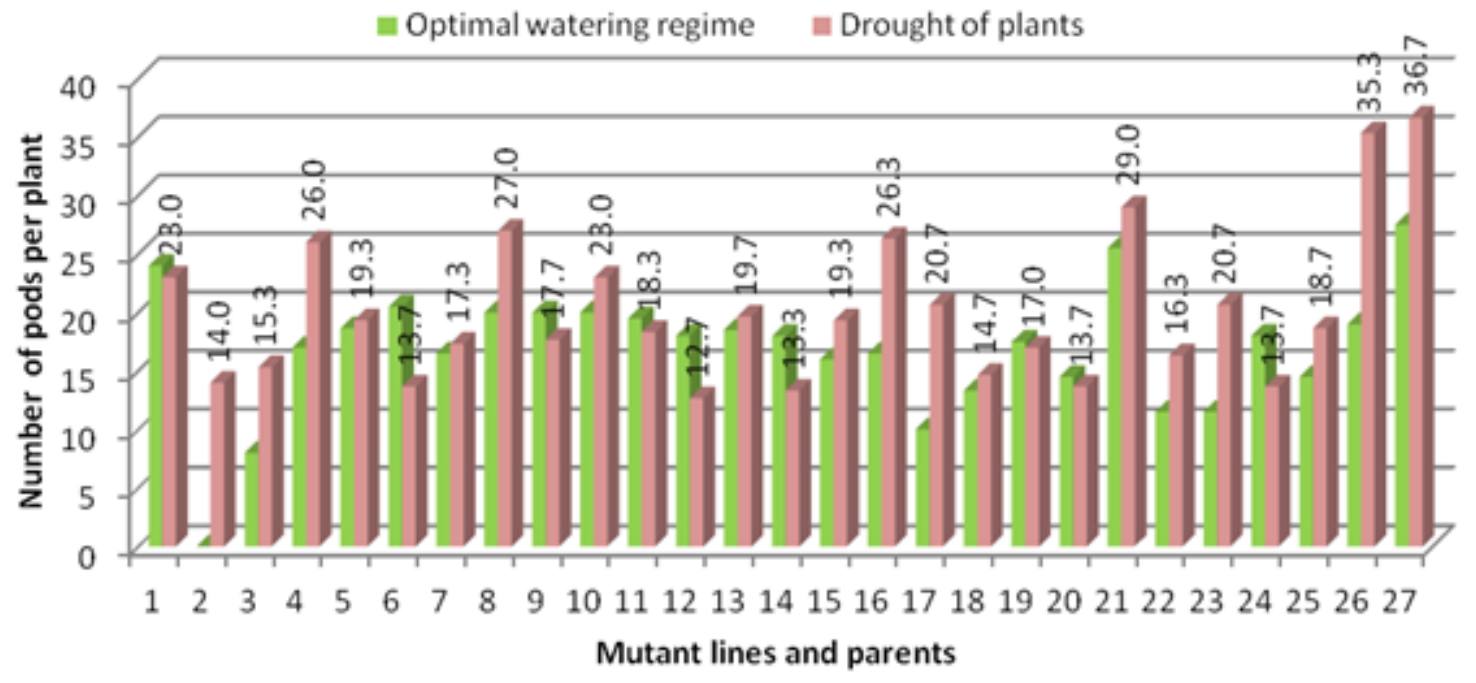

Figure 1. Biometric measurements of beans at economic maturity (number of pods per plant) (Line 
75 years of Agricultural University - Plovdiv JUBILEE SCIENTIFIC INTERNATIONAL CONFERENCE Plovdiv 26-28 November 2020
PERSPECTIVES ON AGRICULTURAL SCIENCE AND INNOVATIONS FOR SUSTAINABLE FOOD SYSTEMS

numbers are presented in Table 2.)

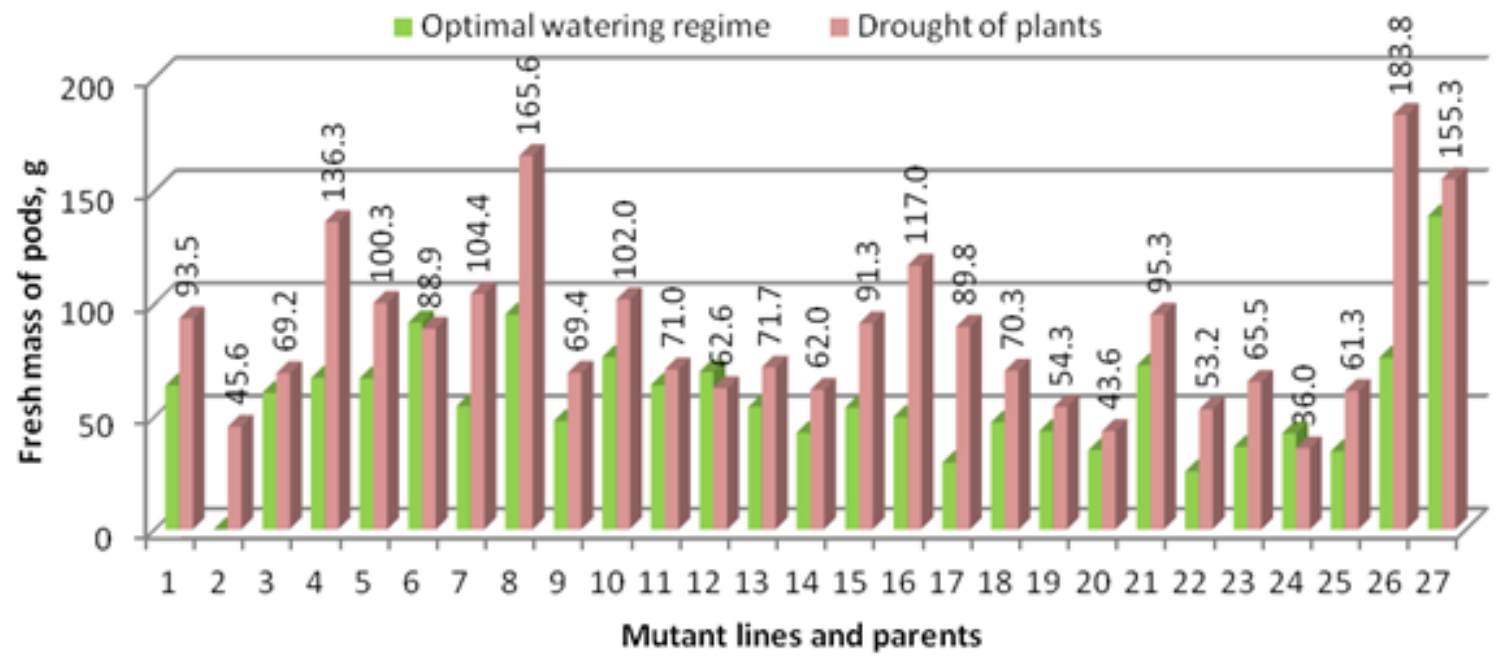

Figure 2. Biometric measurements of pods at consumption maturity (fresh mass of pods, g) (Line numbers are presented in Table 2.)

Table 3. Biometric measurements of bean pods at consumption maturity in drought regime (treated plants)

\begin{tabular}{|c|c|c|c|}
\hline \multirow{2}{*}{ oo } & \multicolumn{3}{|c|}{ Morphology of a bean pod } \\
\cline { 2 - 4 } & $\begin{array}{c}\text { Length, } \\
\text { cm }\end{array}$ & $\begin{array}{c}\text { Width, } \\
\text { cm }\end{array}$ & $\begin{array}{c}\text { Fresh mass, } \\
\text { g }\end{array}$ \\
\hline 1 & 12,60 & 10,95 & 6,66 \\
\hline 2 & 7,87 & 13,12 & 4,12 \\
\hline 3 & 11,02 & 15,84 & 7,34 \\
\hline 4 & 12,78 & 11,32 & 7,58 \\
\hline 5 & 12,77 & 11,05 & 7,23 \\
\hline 6 & 13,02 & 11,69 & 8,33 \\
\hline 7 & 12,13 & 11,68 & 7,90 \\
\hline 8 & 12,76 & 11,15 & 8,21 \\
\hline 9 & 10,15 & 11,65 & 6,46 \\
\hline 10 & 10,74 & 11,26 & 6,59 \\
\hline 11 & 8,76 & 10,43 & 5,38 \\
\hline 12 & 11,87 & 11,59 & 6,55 \\
\hline 13 & 9,69 & 10,88 & 5,50 \\
\hline 14 & 9,24 & 11,12 & 6,11 \\
\hline 15 & 12,22 & 11,87 & 6,93 \\
\hline 16 & 12,11 & 13,01 & 6,37 \\
\hline 17 & 11,85 & 12,66 & 6,50 \\
\hline 18 & 13,98 & 12,83 & 7,27 \\
\hline 19 & 11,78 & 12,69 & 5,96 \\
\hline 20 & 10,57 & 11,89 & 5,48 \\
\hline 21 & 11,19 & 9,39 & 4,87 \\
\hline 22 & 9,21 & 10,26 & 4,71 \\
\hline 23 & 11,17 & 10,43 & 4,70 \\
\hline 24 & 9,42 & 9,88 & 4,04 \\
\hline 25 & 11,91 & 9,35 & 5,10 \\
\hline 26 & 12,71 & 11,38 & 7,39 \\
\hline 27 & 12,45 & 11,25 & 7,18 \\
\hline & & & \\
\hline
\end{tabular}

Biometric measurements of pods, the major component of the yield, showed a variation in the studied indicators. On the basis of the pod length, the values were in the range from $9.24 \mathrm{~cm}$ to $13.98 \mathrm{~cm}$, the width of the pods was in the range from $9.35 \mathrm{~mm}$ to $13.01 \mathrm{~mm}$, and the fresh weight of one pod was from 4.04 $\mathrm{g}$ to $8,33 \mathrm{~g}$ (Table 3 ).

The productivity index gives a significant estimate of the percentage of fresh mass of bean pods to the total biomass of the plant (Table 4). This indicator has the highest value of $81.46 \%$ at line 26 (M 564-193-9-1-1), followed by line 8 (M 564-190-1-1-1), line 4 (M 564 -110-1-2), line 7 (M 564-175-3-1A), line 16 (M 564-191-1-1-2), line 10 (M 564-190-3-5), line 21 (M 564-193-8-1A), with an increase of $79.00 \%, 73.68 \%, 73.50 \%, 72.07 \%, 71.91 \%$ and $70.86 \%$, respectively. The highest average bean pod mass of the tested mutant lines compared to the control was in lines 26 (M 564193-9-1-1), 8 (M 564-190-1-1-1) and 27 (M 564- 193-9-1-2), $132.39 \%, 119.29 \%$ and $111.85 \%$, respectively. 
75 years of Agricultural University - Plovdiv JUBILEE SCIENTIFIC INTERNATIONAL CONFERENCE Plovdiv 26-28 November 2020
PERSPECTIVES ON AGRICULTURAL SCIENCE AND INNOVATIONS FOR SUSTAINABLE FOOD SYSTEMS
Table 4. Productivity index for mutant bean lines in drought conditions

\begin{tabular}{|c|c|c|c|c|c|}
\hline № & $\begin{array}{c}\text { Fresh } \\
\text { leaf - } \\
\text { stem } \\
\text { mass, g }\end{array}$ & $\begin{array}{c}\text { Fresh } \\
\text { mass of } \\
\text { pods, g }\end{array}$ & $\begin{array}{c}\text { Total } \\
\text { bioma } \\
\text { ss, g }\end{array}$ & $\begin{array}{c}\text { mass } \\
\text { of } \\
\text { pods, } \\
\%\end{array}$ & $\begin{array}{c}\text { mass } \\
\text { of pods } \\
/ \mathrm{K}, \%\end{array}$ \\
\hline 1 & 45,33 & 93,52 & 138,85 & 67,35 & 100,00 \\
\hline 2 & 46,50 & 45,57 & 92,07 & 49,49 & 32,82 \\
\hline 3 & 46,33 & 69,19 & 115,52 & 59,89 & 49,83 \\
\hline 4 & 48,67 & 136,25 & 184,92 & 73,68 & 98,13 \\
\hline 5 & 45,83 & 100,30 & 146,13 & 68,64 & 72,24 \\
\hline 6 & 47,33 & 88,94 & 136,27 & 65,27 & 64,05 \\
\hline 7 & 37,63 & 104,39 & 142,02 & 73,50 & 75,18 \\
\hline 8 & 44,03 & 165,63 & 209,66 & 79,00 & 119,29 \\
\hline 9 & 44,10 & 69,43 & 113,53 & 61,16 & 50,00 \\
\hline 10 & 39,83 & 101,97 & 141,80 & 71,91 & 73,44 \\
\hline 11 & 38,33 & 70,96 & 109,29 & 64,93 & 51,11 \\
\hline 12 & 47,70 & 62,60 & 110,30 & 56,75 & 45,08 \\
\hline 13 & 36,50 & 71,73 & 108,23 & 66,28 & 51,66 \\
\hline 14 & 34,17 & 61,96 & 96,13 & 64,45 & 44,62 \\
\hline 15 & 49,00 & 91,33 & 140,33 & 65,08 & 65,78 \\
\hline 16 & 45,33 & 116,99 & 162,32 & 72,07 & 84,26 \\
\hline 17 & 47,17 & 89,84 & 137,01 & 65,57 & 64,70 \\
\hline 18 & 54,00 & 70,34 & 124,34 & 56,57 & 50,66 \\
\hline 19 & 51,83 & 54,26 & 106,09 & 51,15 & 39,08 \\
\hline 20 & 49,10 & 43,61 & 92,71 & 47,04 & 31,41 \\
\hline 21 & 39,17 & 95,27 & 134,44 & 70,86 & 68,61 \\
\hline 22 & 42,17 & 53,19 & 95,36 & 55,78 & 38,31 \\
\hline 23 & 40,00 & 65,49 & 105,49 & 62,08 & 47,17 \\
\hline 24 & 31,67 & 36,03 & 67,70 & 53,22 & 25,95 \\
\hline 25 & 40,00 & 61,26 & 101,26 & 60,50 & 44,12 \\
\hline 26 & 41,83 & 183,83 & 225,66 & 81,46 & 132,39 \\
\hline 27 & 78,87 & 155,31 & 234,18 & 66,32 & 111,85 \\
\hline
\end{tabular}

\section{CONCLUSIONS}

When the mutant bean lines were grown in the same agroclimatic conditions under drought treatment, the early $\left(\mathrm{M}_{4}\right)$ mutant lines are №26 (M 564-193-9-1-1 ) and №27 (M 564193-9-1-2), followed by № 8 (M 564-190-1-11), № 4 (M 564-110-1-2) and № 16 M 564-1911-1-2), stood out, compared with the parent line №1 (L 564), the other mutants from the experiment and the variety Mastilen $11 \mathrm{~b}$ according to the biometric measurements of the treated plants in consumption maturity with the highest productivity.
Plants from the early mutant line № 21 (M 564-193-8-1A) formed more bean pods than those of the parent line №1, but they have lower values of length, width and fresh weight of one pod.

Treated plants with the reduced irrigation regime (water deficit) delayed development and phenophases from 7 to 10 days were later than those with the optimal irrigation.

The mutant line № 25 (M 564-193-8-5) differed from all treated early mutant lines and was selected as the earliest one.

\section{ACKNOWLEDGMENT}

This work was supported by the Bulgarian Ministry of Education and Science under the National Research Programme "Healthy Foods for a Strong Bio-Economy and Quality of Life" approved by DCM \# 577 / 17.08.2018".

\section{REFERENCES}

Araus, J.L., G.A. Slafer, M.P. Reynolds, C. Royo, 2002. Plant breeding and drought in C3 cereals: what should we breed for? Ann. Bot. 89, 925-940.

Dai, A., 2013. Increasing drought under global warming in observations and models. Nature Climate Change, 3: 52.

DaMatta, F.M., 2004. Exploring drought tolerance in coffee: a physiological approach with some insights for plant breeding, Braz. J. Plant Physiol. 16, 1-6.

Dingkuhn, M., F. Asch, 1999. Phenological responses of Oryza sativa, $O$. glaberrima and inter-specific rice cultivars on a toposquence in West Africa, Euphytica 110, 109-126.

Figueiredo, B., R. Martinez, A. Burity, P. Chanway, 2008. Plant growthpromoting rhizobacteria for improving nodulation and nitrogen fixation in the common bean (Phaseolus vulgaris L.). 
75 years of Agricultural University - Plovdiv JUBILEE SCIENTIFIC INTERNATIONAL CONFERENCE Plovdiv 26-28 November 2020

World Journal of Microbiology and Biotechnology, 24 (7), 1187-1193.

Koehler, H., H. Chang, G. Scheier, W. Burke, 1987. Nutrient composition, protein quality, and sensory properties of thirtysix cultivars of dry beans (Phaseolus vulgaris L.). Journal of Food Science, 52(5), 1335-1340.

Olivera, M., N. Tejera, C. Iribarne, A. Ocana, C. Lluch, 2004. Growth, nitrogen fixation and ammonium assimilation in common bean (Phaseolus vulgaris): effect of phosphorus. Physiologia Plantarum, 121(3), 498- 505.

Piha, I., N. Munns, 1987. Nitrogen fixation potential of beans (Phaseolus vulgaris L.) compared with other grain legumes under controlled conditions. Plant and Soil, 98(2), 169-182.

Rao, I. M,. 2014. Advances in improving adaptation of common bean and Brachiaria forage grasses to abiotic stresses in the tropics, in Handbook of Plant and Crop Physiology, ed. M. Pessarakli (Boca Raton, FL: CRC Press; Taylor and Francis Group), 847-889.

Rippke, U., J. Ramirez-Villegas, A. Jarvis, S.J. Vermeulen, L. Parker, and F. Mer, 2016. Timescales of transformational climate change adaptation in subSaharan African agriculture. Nature Climate Change, 6: 605-609. 